\title{
Ludicidade / Playfulness
}

https://doi.org/10.21814/uminho.ed.36.41

\section{Alberto Nídio Silva}

CIEC - Centro de Investigação em Estudos da Criança da Universidade do Minho, Portugal 



\section{Ludicidade}

\section{Lu·di.ci·da·de}

Qualidade do que é lúdico. Relativo a jogos, brinquedos e brincadeiras; Brincadeira.

Ação que visa mais ao divertimento do(s) ator(es) do que a qualquer outro objetivo; o que se faz por gosto sem outro objetivo que não seja o próprio prazer de o fazer e de quem o faz; Status relativo à tendência ou manifestação que surge na infância e na adolescência sob a forma de jogo regulado ou ação de livre expressão dos seus autores e atores num momento e tempo dados.

Expressão da cultura lúdica das crianças num contexto próprio e do estado em que se objetivam e afirmam primordialmente as culturas da Infância (James, Jenks \& Prout, 1998, p. 99). "No centro da cultura infantil encontra-se refletida, sobre o demais, a ludicidade e, nesta, a cultura lúdica [...] que permite às crianças que não se conhecem e se encontrem num jardim público, por exemplo, poder jogar em conjunto ao gato e ao rato, pé-coxinho, escondidinho, acordando rapidamente as regras, porque possuem um mesmo património lúdico" (Delalande, 2006, p. 270).

Nesta especificidade que a ludicidade encontra na infância e na(s) cultura(s) que lhe é muito própria, coexistem momentos definidores da alteridade que a distingue da ludicidade na adultez.

Dentro da sua peculiaridade, ninguém consegue pensar o mundo das crianças despido do seu mundo outro dos brinquedos e das brincadeiras, tal é a dimensão da sua presença, determinante nas diversas fases da construção das suas relações sociais, da recriação dos contextos societários onde vivem e na produção das fantasias que alimentam os seus riquíssimos imaginários que emolduram as brincadeiras hilariantes de um quotidiano impossível de pensar sem a sua existência. O saber lúdico, recorda Delalande, "aparece como a parte mais evidente e, sem dúvida, igualmente, como a que os adultos melhor reconhecem do saber infantil" (2006, p. 269), como, aliás, todo o adulto lembra sem qualquer esforço mental, até porque todos nós já fomos 
um dia crianças, brincamos, e desse tempo guardamos memórias vivas que nos falam dessa realidade.

Na infância, entre as crianças, ludicidade e cultura lúdica constituem elementos indissociáveis na condição e expressão em que se apresentam. É aí que se cruzam, como anota Brougère (1998, p. 30), o papel das experiências vividas, a aprendizagem paulatina e progressiva ao longo da infância, a agregação de elementos heterogéneos provenientes de fontes diversas, a interação grupal com toda a carga simbólica de aporte de novas e cada vez mais complexas competências, a interpretação e aplicação das regras, a importância da criatividade, numa panóplia de saberes e fazeres que se assumem como contributos decisivos para a competência do brincante perante o brinquedo e a sua vida de todos os dias.

Infância e ludicidade constituem, pois, um binómio umbilicalmente ligado num compromisso de importância seminal para a formação da criança face à dimensão que a presença do lúdico (jogos, brinquedos e brincadeiras) consubstanciam em todo o processo de formação do indivíduo e da concomitante utilidade de que aí e desde o dealbar da vida se caracteriza toda a presença da atividade lúdica (Foulquié, 1952) que se (con)funde de uma forma incontornável e permanente com as vivências que enformam socialmente a vida de todas as crianças, com particular enfoque na que se desenvolve no interior do próprio grupo. Nesta relação de cumplicidade tácita floresce uma cultura (cultura lúdica) que, como nos seus trabalhos de campo constatou Delalande (2006), tem um papel absolutamente central dentro da cultura infantil, permitindo a abertura de corredores por onde passa a sociabilidade de atores que, por força do domínio de um património lúdico que lhes é comum, conhecem uma mesma linguagem específica em toda a sua dimensão, fazendo dela passaporte seguro para as interações grupais que lhes enriquecem o quotidiano e a consequente preparação para a vida.

Até há tempos não muitos idos, a cultura lúdica que substanciava a ludicidade do mundo das crianças foi marcada por uma quase imutabilidade do seu quadro configurador, com um processo de aquisição em contexto real, vivendo de uma experiência aí exercitada e acumulada pelas crianças desde o berço até à adolescência, predominantemente em grupo e interação informais cara a cara, com irmãos, vizinhos, amigos e companheiros de escola, e, maioritariamente, fora de casa. A cultura lúdica contemporânea, como no-lo refere Brougère (2005), vestiu-se de outras especificidades, nomeadamente as que comportam formas solitárias de jogo, com interações 
diferidas com os objetos portadores de ações e significações, sobretudo as que têm particular expressão nos jogos de vídeo portadores de novas técnicas criadoras de experiências lúdicas inovadoras que transformam a cultura lúdica de inúmeras crianças. A Era Digital virtualizou a ludicidade e quase the volatilizou as formas outras de expressão face-a-face que, historicamente, conheceu na infância e nas crianças através dos tempos.

\section{Playfulness}

Quality of what is playful. Relating to games, toys and play; playing.

Action aimed more at entertaining the ator(s) than any other goal; that is done for pleasure without any other purpose than the pleasure of doing it and for the person who is doing it; Status regarding the tendency or manifestation that arises in childhood and adolescence in the form of a game. Expression of the playful culture of children in a given context and the state in which the cultures of Childhood are primarily objetify and affirmed. (James, Jenks and Prout, 1998, p. 99). “At the heart of children's culture is playfulness and the playful culture [...] which allows children who do not know each other and find themselves in a public park, for example, to be able to play together with games like tag, hide and seek, and hopscotch, quickly agreeing on the rules because they have the same playful heritage" (Delalande, 2006, p. 270).

In this specificity that playfulness encounters in childhood and in its own culture(s), there are defining, coexisting moments of otherness that distinguish playfulness from adulthood.

Within its peculiarity, no one can think of the world of children stripped of their vast world of toys and play, which are decisive in the different phases of the construction of their social relationships, to re-create of the social contexts where they live and in the production of the fantasies that nourish their rich imaginations that frame the amusing games of daily life, inconceivable without play. Playful knowledge, Delalande recalls, "appears as the most evident part, and undoubtedly equally, as that which adults best recognize in childhood knowledge" (2006, p. 269), as, indeed, every adult remembers without any mental effort that he or she played, because we were all children once, and we hold living memories that remind us of this reality.

In childhood, among children, playfulness and playful culture are inseparable elements in their condition and expression. This is where Brougère 
(1998, p. 30) notes the role of lived experiences, the gradual and progressive learning throughout childhood, the aggregation of heterogeneous elements from different sources, the group interaction with the symbolic load of new and increasingly complex competences, the interpretation and application of rules, the importance of creativity, in a panoply of knowledge and actions that are assumed as decisive contributions to the competency of the player in relation to the toy and daily life in general.

Childhood and playfulness therefore constitute an umbilically linked binomial of seminal importance for the development of the child. Considering the importance of playfulness (games, toys and play) in the whole process of the development of the individual since the beginning of life, playful activity is characterized (Foulquié, 1952) as merging in an unavoidable and permanent way with the experiences that socially shape the lives of all children, with a particular focus on those experiences within the group itself. In this relationship of tacit complicity, a culture (playful culture) flourishes, and as Delalande (2006) found in his fieldwork, plays an absolutely central role in children's culture, opening opportunities for the sociability of the actors, who, by virtue of a dominant common playful heritage, share the same specific language in all its dimensions, making it a safe passport for group interactions that enrich their daily lives and their consequent preparation for life.

Until not too long ago, the playful culture that substantiated play in the world of children was characterised by an almost immutable configuring framework, with a process of acquisition in a real context, based on experiences accumulated by the children from birth to adolescence, predominantly in group and informal face-to-face interactions with siblings, neighbors, friends and schoolmates and, mostly, away from home. Contemporary playful culture, as mentioned by Brougère (2005), has demonstrated other specificities, namely those containing solitary forms of play, with differing interactions with objects that have associated actions and meanings, especially those that are expressed through video games with new techniques that create innovative play experiences, which transform the play culture of countless children. The Digital Era has virtualized playfulness and almost effaced the other forms of face to face playful expression, historically present in childhood and among children over the course of time. 


\section{Referências / References}

Brougère, G. (1998). A criança e a cultura lúdica. In T. Kishimoto, Brincar e suas Teorias (pp. 19-32). São Paulo: Pioneira.

—(2005). Jouer/Apprendre. Paris: Economica Anthropos.

Delalande, J. (2003). Culture Enfantine et Régles de Vie. Jeux e enjeux de la cour de récréation. Terrain, 40, 99-114.

- (2006). Le Concept Heuristique de Culture Enfantine. In R. Sirota (org.), Elements pour une sociologie de l'enfance (pp. 267-274). Rennes: Presses Universitaires de Rennes.

Foulquié, P. (1952). As Escolas Novas. São Paulo: Companhia Editora Nacional.

James, A., Jenks, C. \& Prout, A. (1998). Theorizing Childhood. Cambridge: Polity Press.

Sarmento, M. J. (2004). As Culturas da Infância nas Encruzilhadas da 2.a Modernidade. In M. J. Sarmento \& A. B. Cerisara (Eds.), Crianças e Miúdos. Perspetivas Sociopedagógicas da Infância (pp. 9-34). Porto: ASA.

Silva, A. N. (2011). Jogos, Brinquedos e Brincadeiras-Trajetos Intergeracionais. Vila Verde: Atahca. 